${ }^{\odot}$ М. С. Гнатюк, К. А. Походун, Л. В. Татарчук

ДВНЗ «Тернопільсъкий державний медичний університет імені І. Я. Горбачевсъкого МОЗ України»

\title{
МОРФОМЕТРИЧНА ОЦІНКА ОСОБЛИВОСТЕЙ РЕМОДЕЛЮВАННЯ АРТЕРІЙ ПЛАЦЕНТИ ПРИ ЗАЛІЗОДЕФІЦИТНІЙ АНЕМІї ВАГІТНИХ
}

Мета дослідження - морфометричне вивчення особливостей ремоделювання артерій плаценти при залізодесріцитній анемії вагітних.

Матеріали та методи. Комплексом морфологічних методів досліджені плаценти 25 жінок, які були розділені на дві групи. Перша група (контрольна) включала 10 плацент від жінок, вагітність яких проходила без анемії, а також із відсутністю різних патологій посліду, друга - 15 плацент жінок, де при вагітності було діагностовано залізодесріцитну анемію 1 ст. На гістологічних препаратах плаценти проводили морфометрію стовбурових артерій середнього (51-125 мкм) та дрібного (26-50 мкм) калібрів. При цьому вимірювали зовнішній та внутрішній діаметри артерій, товщини медії та адвентиції, висоту ендотеліоцитів, діаметр їх ядер, визначали індекс Вогенворта, ядерно-цитоплазматичні відношення в ендотеліоцитах та відносний об'єм ушкоджених ендотеліоцитів. Кількісні показники обробляли статистично.

Результати дослідження та їх обговорення. Встановлено, що залізодефріцитна анемія вагітних призводила до вираженої структурної перебудови артеріального русла з домінуванням морфологічних змін в артеріях дрібного калібру плаценти. Зовнішній діаметр даних судин при цьому виявився збільшеним на 2,3 \% порівняно з контролем, а їх внутрішній діаметр зменшився на 12,6 \%. Товщина медії артерій дрібного калібру зросла на 17,4 \%, товщина адвентиції - на 17,6 \%, індекс Вогенворта - у 1,4 раза. У даних патологічних умовах на 4,9 \% змінилася висота ендотеліоцитів, а ядерно-цитоплазматичні відношення у цих клітинах - на 13,3 \%. Останній морфометричний параметр вказував на виражене порушення структурного клітинного гомеостазу в ендотеліоцитах. Відносний об'єм ушкоджених ендотеліоцитів при цьому зріс у 12 разів.

Висновки. Залізодефріцитна анемія вагітних призводить до вираженого ремоделювання артерій плаценти, яке характеризується потовщенням їхньої стінки, звуженням просвіту, зростанням індексу Вогенворта, зниженням їх пропускної здатності, ураженням ендотеліоцитів, ендотеліальною дисфункцією, погіршанням кровопостачання органа, гіпоксією, дистрофрією, некробіозом клітин і тканин. При залізодефріцитній анемії вагітних більш виражена структурна перебудова спостерігається в артеріях дрібного калібру плаценти.

Ключові слова: залізодефріцитна анемія вагітних; плацента; артерії.

МОРФОМЕТРИЧЕСКАЯ ОЦЕНКА ОСОБЕННОСТЕЙ РЕМОДЕЛИРОВАНИЯ АРТЕРИЙ ПЛАЦЕНТЫ ПРИ ЖЕЛЕЗОДЕФИЦИТНОЙ АНЕМИИ БЕРЕМЕННЫХ

Цель исследования - морфометрическое изучение особенностей ремоделирования артерий плаценты при железодесрицитной анемии беременных.

Материалы и методы. Комплексом морфологических методов исследованы плаценты 25 женщин, которые были разделены на две группы. Первая группа (контрольная) включала 10 плацент женщин, беременность которых протекала без анемии и при отсутствии разных патологий последа, вторая - 15 плацент женщин, где при беременности была диагностирована железодесицитная анемия 1 ст. На гистологических препаратах плаценты проводили морфометрию артерий среднего (51-125 мкм) и мелкого (26-50 мкм) калибров. При этом измеряли внешний и внутренний диаметры артерий, толщины медии, адвентиции, высоту эндотелиоцитов, диаметр их ядер, определяли индекс Вогенворта, ядерно-цитоплазматические отношения в эндотелиоцитах и относительный объем поврежденных эндотелиоцитов. Количественные показатели обрабатывали статистически.

Результаты исследования и их обсуждение. Выявлено, что железодефицитная анемия беременных приводила к выраженной структурной перестройке артериального русла з доминированием морфологических изменений в артериях мелкого калибра плаценты. Внешний диаметр этих сосудов при этом увеличился на 2,3 \% в сравнении с контролем, а внутренний диаметр уменьшился на 12,6 \%. Толщина медии артерий мелкого калибра увеличилась на 17,4 \%, толщина адвентиции - на 17,6 \%, индекс Вогенворта - у 1,4 раза. В данных патологических условиях на 4,9 \% изменилась высота эндотелиоцитов, а ядерно-цитоплазматические отношения в этих клетках - на 13,3 \%. Последний морфометрический параметр указывал на выраженное нарушение структурного клеточного гомеостаза в эндотелиоцитах. Относительный объем поврежденных эндотелиоцитов при этом увеличился в 12 раз.

Выводы. Железодефицитная анемия беременных приводит к выраженному ремоделированию артерий плаценты, которое характеризуется утолщением их стенки, сужением просвета, увеличением индекса Вогенворта, снижением их пропускной возможности, поражением эндотелиоцитов, эндотелиальной дисфункцией, ухудшением кровоснабжения органа, гипоксией, дистрофией, некробиозом клеток и тканей. При железодефицитной анемии беременных более выраженная структурная перестройка наблюдается в артериях мелкого калибра плаценты.

Ключевые слова: железодесрицитная анемия беременных; плацента; артерии.

MORPHOMETRIC EVALUATION OF PLACENTA ARTERIES REMODELING FEATURES AT IRON DEFICIENCY ANEMIA IN PREGNANT WOMEN

The aim of the study - the morphometric study of the remodeling features of arteries in the placenta with iron deficiency anemia in pregnant women. 
Materials and Methods. With the complex of morphological methods we examined the placenta of 25 women, who were divided into two groups. The first group (control) included 10 placenta from women whose pregnancy was without anemia and the absence of various pathologies, the second - 15 placenta women, where during pregnancy was diagnosed with iron deficiency anemia 1 item. The histologic preparations of the placenta were morphometry of the arteries of the middle (51-125 microns) and small calibres (26-50 microns). In this case, the external and internal diameters of the arteries, the thickness of the media and adventitia, the height of the endothelial cells, the diameter of their nuclei, the Wogenworts index, the nuclear-cytoplasmic ratio in the endothelial cells and the relative volume of the damaged endothelial cells were measured. Quantitative indicators were processed statistically.

Results and Discussion. It was established that iron deficiency anemia in pregnant women resulted in a marked structural reconstruction of the arterial bed with the predominance of morphological changes in the arteries of the small caliber of the placenta. The outer diameter of the vessel data in this case was increased by $2.3 \%$ compared with the control, and their internal diameter decreased by $12.6 \%$. The thickness of the media artery of small caliber has increased by $17.4 \%$, the thickness of the adventitia - by $17.6 \%$, the Wogenvorts index - 1.4 times. In these pathological conditions, the height of endothelial cells has changed by $4.9 \%$, and the nuclear-cytoplasmic ratio in these cells is $13.3 \%$. The last morphometric parameter indicated a marked violation of structural cellular homeostasis in endothelial cells. Relative volume of damaged endothelial cells in this case increased 12 times.

Conclusions. Iron deficiency anemia in pregnant women results in pronounced remodeling of the arteries of the placenta, which is characterized by thickening of their walls, narrowing of the lumen, growth of the Wogenworts index, decrease in their throughput, endothelial cell lesion, endothelial dysfunction, deterioration of blood supply to the organ, hypoxia, dystrophy, necrobiosis of cells and tissues. With iron deficiency anemia in pregnant women, a more pronounced structural reconstruction is observed in the arteries of the small caliber of the placenta.

Key words: iron deficiency anemia in pregnant women; placenta; arteries.

Вступ. Незважаючи на успіхи сучасної медичної науки, залізодеоріцитна анемія вагітних нерідко зустрічається у клініці, а в різних регіонах України ії частота коливається від 28,4 до 83,1 \% [5]. Дана патологія вагітних залишається важливою проблемою в акушерстві і призводить до виникнення цілої низки ускладнень як у матері, так і дитини, таких, як: гестоз, хронічна гіпоксія плода, невиношування вагітності, синдром затримки внутрішньоутробного розвитку плода, аномалії пологової діяльності [3]. Варто зазначити, що морфологію плаценти вивчали при анеміях вагітних, в той же час особливості ремоделювання ії артеріального русла при вказаній патології досліджені недостатньо.

МЕТА ДОСЛІДЖЕННЯ - морфометричне вивчення особливостей ремоделювання артерій плаценти при залізодефіцитній анемії вагітних.

МАТЕРІАЛИ ТА МЕТОДИ. Комплексом морфологічних методів досліджені плаценти 25 жінок, які були розділені на дві групи. Перша група (контрольна) включала 10 плацент від жінок, вагітність яких проходила без анемії, а також з відсутністю різних патологій посліду, друга - 15 плацент жінок, де при вагітності було діагностовано залізодесріцитну анемію 1 ст. Діагноз залізодесріцитної анемії встановлювали за показниками вмісту гемоглобіну, кількості еритроцитів, кольорового показника, гематокриту, рівня сироваткового заліза. Визначення ступеня анемії проводили з використанням Міжнародної класифрікації хвороб Х перегляду, заснованої за рекомендаціями ВООЗ (1998), залежно від вираженості анемії: 1 ст. - Hb - 110-91 г/л; II ст. - Hb - 90-71 г/л; III ст. - Нb - 70-51 г/л; IV ст. - Нb 50 і менше г/л. Після розродження у всіх жінок вирізали шматочки плаценти, які фріксували у 10 \% нейтральному розчині формаліну і після проведення через етилові спирти зростаючої концентрації поміщали у парафін. Мікротомні зрізи товщиною 5-6 мкм після депарафрінізації забарвлювали гематоксилін-еозином, за Ван Гізоном, Маллорі, Вейгертом, толуїдиновим синім [7]. Гістологічні препарати після світлооптичного вивчення досліджували морфометрично. Проводили морфометрію стовбурових артерій середнього (51-125 мкм) та дрібного (26-50 мкм) калібрів [8] посліду. При морфометрії артерій вимірювали їх зовнішній (ЗД) та внутрішній (ВД) діаметри, товщини медії (ТМ) та адвентиції (ТА), висоту ендотеліоцитів (BE), діаметр їх ядер (ДЯЕ), визначали індекс Вогенворта (IB), ядерно-цитоплазматичні відношення в ендотеліоцитах (ЯЦВ) та відносний об'єм ушкоджених ендотеліоцитів (ВОУЕ) $[1,2]$. Морфометрію вказаних судин проводили за допомогою світлового мікроскопа «Olimpus BX-2» 3 цифровою відеокамерою та пакетом прикладних програм «Відео Тест 5,0» та «Відео розмір 5,0». Кількісні показники обробляли статистично. Обробка результатів виконана у відділі системних статистичних досліджень ДВНЗ «Тернопільський державний медичний університет імені І. Я. Горбачевського МОЗ України» у програмному пакеті STATISTIKA. Різницю між порівнювальними величинами визначали за критерієм Стьюдента та Манна - Уїтні [4].

РЕЗУЛЬТАТИ ДОСЛІДЖЕННЯ ТА ЇХ ОБГОВОРЕННЯ. Отримані кількісні морорологічні показники досліджуваного артеріального русла плаценти показані в таблиці 1. Усестороннім аналізом представлених морфометричних параметрів артерій плаценти виявлено, що при залізодесріцитній анемії вагітних вони суттєво змінювалися. Так, зовнішній діаметр артерій середнього калібру при цьому змінився незначно, всього на 0,6 \% порівняно 3 аналогічним контрольним показником. Внутрішній діаметр вказаних судин при цьому з вираженою статистично достовірною різницею ( $<<0,001)$ зменшився на 8,2 \%. Товщина медії артерій середнього калібру плаценти у досліджуваних патологічних умовах статистично достовірно ( $<<0,001)$ збільшилася на 7,3 \%, товщина адвентиції - на 20,7 \%, індекс Вогенворта - у 1,2 раза. Звуження просвіту артерій, зростання товщини медії, адвентиції, індексу Вогенворта свідчили про зниження пропускної здатності вказаних судин $[2,8]$.

Висота ендотеліоцитів артерій середнього калібру плаценти при досліджуваній патології зросла з (6,36士 $0,05)$ мкм до $(6,50 \pm 0,05)$ мкм. Наведені морфометричні параметри статистично достовірно $(p<0,05)$ відрізнялися між собою. При цьому останній показник перевищував попередній на 2,2 \%. Діаметри ядер ендотеліоцитів при цьому зі статистично достовірною різницею $(p<0,01)$ зросли на 7,1%. Нерівномірні диспропорційні зміни про- 
Акушерство та гінекологія -

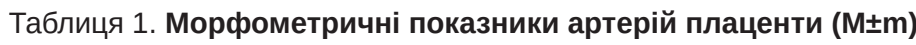

\begin{tabular}{|c|c|c|}
\hline \multirow{2}{*}{ Показник } & \multicolumn{2}{|c|}{ Група спостереження } \\
\hline & 1-ша & 2-га \\
\hline \multicolumn{3}{|c|}{ Артерії середнього калібру } \\
\hline ЗД, мкм & $85,60 \pm 0,72$ & $86,10 \pm 0,81$ \\
\hline ВД, мкм & $45,20 \pm 0,33$ & $41,50 \pm 0,30^{\star \star \star *}$ \\
\hline ТМ, мкм & $21,90 \pm 0,15$ & $23,50 \pm 0,18^{\star \star *}$ \\
\hline ТА, мкм & $12,10 \pm 0,12$ & $14,60 \pm 0,25^{\star \star \star *}$ \\
\hline $\mathrm{IB}, \%$ & $353,9 \pm 4,2$ & $430,4 \pm 5,1^{\star \star \star}$ \\
\hline BE, мкм & $6,36 \pm 0,05$ & $6,50 \pm 0,05^{\star}$ \\
\hline ДЯЕ, МКМ & $3,38 \pm 0,03$ & $3,62 \pm 0,03^{\star *}$ \\
\hline ЯЦВ & $0,282 \pm 0,002$ & $0,310 \pm 0,003^{* \star *}$ \\
\hline BOУE, \% & $2,30 \pm 0,02$ & $15,60 \pm 0,18^{\star \star \star}$ \\
\hline \multicolumn{3}{|c|}{ Артерії дрібного калібру } \\
\hline ЗД, мкм & $34,80 \pm 0,24$ & $35,60 \pm 0,27$ \\
\hline ВД, мкм & $13,50 \pm 0,15$ & $11,80 \pm 0,12^{\star \star \star}$ \\
\hline TM, мКМ & $8,60 \pm 0,06$ & $10,10 \pm 0,09 * \star \star *$ \\
\hline TA, мкм & $6,80 \pm 0,06$ & $8,00 \pm 0,09$ *** \\
\hline IB, \% & $664,5 \pm 5,4$ & $910,2 \pm 7,8^{\star \star \star}$ \\
\hline BE, мкм & $6,10 \pm 0,05$ & $5,80 \pm 0,05^{\star \star}$ \\
\hline ДЯЕ, мкм & $3,22 \pm 0,03$ & $3,25 \pm 0,03$ \\
\hline ЯЦВ & $0,278 \pm 0,002$ & $0,315 \pm 0,03^{\star \star \star}$ \\
\hline ВОУЕ, \% & $2,40 \pm 0,02$ & $28,90 \pm 0,24^{\star \star \star *}$ \\
\hline
\end{tabular}

Примітка. * - p<0,05; ** - p<0,01; *** - p<0,001 порівняно з 1-ю групою.

сторових характеристик цитоплазми ендотеліоцитів та їхніх ядер призводили до порушень відношень між ними, що адекватно відображали ядерно-цитоплазматичні відношення у вказаних клітинах. Названий морфометричний параметр при цьому з високим ступенем статистичної достовірності $(p<0,001)$ збільшився на 9,9 \% і вказував на виражене порушення структурного клітинного гомеостазу [6]. Відносний об'єм уражених ендотеліоцитів у досліджуваних судинах 2-ї групи спостережень зріс майже у 6,8 раза.

Аналізом морфометричних параметрів артерій дрібного калібру плаценти встановлено, що при досліджуваній патології вони змінювалися більш виражено порівняно з попередніми судинами. Так, зовнішній діаметр даних судин при цьому виявився збільшеним на 2,3 \% $(p<0,05)$ порівняно з контролем. Внутрішній діаметр артерій дрібного калібру плаценти з вираженою статистично достовірною різницею $(p<0,001)$ у 2-й групі спостережень зменшився на 12,6 \%. Товщина медії досліджуваних судин статистично достовірно $(\mathrm{p}<0,001)$ зросла на $17,4 \%$, товщина адвентиції - на 17,6 \%, індекс Вогенворта - майже у 1,4 раза. Останній морфометричний параметр свідчив про виражене зниження пропускної здатності артерій дрібного калібру $[2,8]$ плаценти при залізодеоріцитній анемії вагітних.

У даних патологічних умовах статистично достовірно ( $<<0,01)$ на 4,9 \% змінилася висота ендотеліоцитів, а ядерно-цитоплазматичні відношення у цих клітинах - на 13,3 \%. Останній морфометричний параметр вказував на виражене порушення структурного клітинного гомеостазу у даних клітинах $[1,6]$. Відносний об'єм ушкоджених ендотеліоцитів при цьому зріс у 12 разів порівняно 3 аналогічним контрольним показником. Відомо, що не- ушкоджені артерії дрібного калібру органів знаходяться у більшому функціональному напруженні порівняно 3 артеріями більших розмірів і вони першими та більш виражено уражаються у різних патологічних умовах $[2,6]$.

Світлооптично у досліджуваних судинах відмічали набряк ендотеліоцитів, їх дистрофрію, некробіоз, апоптоз, десквамацію та проліферацію. Остання підтверджувала наявність гіпоксії. Виявлялося просякання мембран, ендотеліоцитів, судинної стінки білками плазми. У деяких досліджуваних судинах спостерігали осередки орібриноїдного набряку та некрозу, що свідчило про виражене їх пошкодження.

Відомо, що ендотеліоцити судин синтезують різні біологічно активні речовини, необхідні для регуляції життєво важливих процесів організму і зсідання крові, регуляції тонусу судин, скоротливості серця, дифузії води, іонів, продуктів метаболізму. Ендотеліоцити здійснюють бар'єрну, продукційну, гемостатичну, метаболічну, транспортну, репаративну фрункції, синтезують оксид азоту (NO). Пошкодження значної кількості ендотеліоцитів може призводити до їхньої дисфункції, блокади NOсинтази, зменшення синтезу NO, активації процесів його деградації, що супроводжується спазмом та звуженням судин [2]. Останнє погіршує кровопостачання органів, призводить, підтримує та посилює гіпоксію, яка ускладнюється набряком, дистросрією, некробіозом тканин і клітин. Наведене підтверджувалося результатами проведеного дослідження. При значному пошкодженні ендотеліоцитів ступінь морфологічних змін у плаценті був вираженішим.

ВИСнОВКИ. 1. Залізодефіцитна анемія вагітних призводить до вираженого ремоделювання артерій плаценти, яке характеризується потовщенням їхньої стінки, звуженням просвіту, зростанням індексу Вогенворта, зниженням 
їх пропускної здатності, ураженням ендотеліоцитів, ендотеліальною дисфункцією, погіршанням кровопостачання органа, гіпоксією, дистрофією, некробіозом клітин і тканин.

2. При залізодесріцитній анемії вагітних більш виражена структурна перебудова спостерігається в артеріях дрібного калібру плаценти.

\section{СПИСОК ЛІТЕРАТУРИ}

1. Автандилов Г. Г. Основы количественной патологической анатомии / Г. Г. Автандилов. - М. : Медицина, 2002. - 240 с.

2. Гнатюк М. С. Морфометричні аспекти артерій шлуночків серця при його гіперфункції / М. С. Гнатюк, Л. В. Татарчук, О. Б. Слабий // Клінічна анатомія та оперативна хірургія. 2012. - Т. 11, № 4. - C. 47-51.

3. Давиденко І. С. Органометричні параметри плаценти при поєднанні залізодесріцитної анемії вагітних та хронічної плацентарної недостатності / І. С. Давиденко // Клінічна анатомія та оперативна хірургія. - 2005. - Т. 5, № 4. - С. 27-29.

4. Лапач С. Н. Статистические методы в медико-биологических исследованиях Excell / С. Н. Лапач, А. В. Губенко, П. Н. Бабич. - К. : Морион, 2001. - 410 с.

\section{REFERENCES}

1. Avtandilov, G.G. (2002). Osnovy kolichestvennoy patologicheskoy anatomii [Basis of quantitative pathological anatomy]. Moscow: Meditsyna [in Russian].

2. Hnatiuk, M.S., Tatarchuk, L.V., \& Slabyi, O.B. (2012). Morfometrychni aspekty arterii shlunochkiv sertsia pry yoho hiperfunktsii [Morphometrical aspects of arteries ventricules of the heart at hyperfunction]. Klinichna anatomiia ta operatyvna khirurhiia - Clinical Anatomy and Operative Surgery, 11, 4, 4751 [in Ukrainian].

3. Davydenko, I.S. (2005). Orhanometrychni parametry platsenty $v$ poiednanni zalizodefiysytnoi anemii u vahitnykh ta khronichnoi platsentarnoi nedostatnosti [Orhanometrica parametrs of placenta in connection iron deficiency anemia in pregnant and chronical placental insufficiently]. Klinichna anatomiia ta operatyvna khirurhiia - Clinical Anatomy and Operative Surgery, 5, 4, 27-29 [in Ukrainian].

4. Lapach, S.G., Gubenko, A.V., \& Babich, P.N. (2001) Statisticheskiye metody $v$ medyko-biologicheskikh issledovani-
ПЕРСПЕКТИВИ ПОДАЛЬШИХ ДОСЛІДЖЕНЬ. Всебічне, адекватне, повноцінне вивчення структурної перебудови артеріального русла плаценти при залізодефріцитній анемії вагітних дозволить суттєво розширити діагностику, корекцію та профрілактику уражень досліджуваного органа.

5. Лук'янова О.М. Актуальні проблеми перинатології на сучасному етапі охорони здоров'я / О. М. Лук'янова // Перинатологія та педіатрія. - 2002. - № 3. - С. 3-6.

6. Саркисов Д. С. Структурные основы адаптации и компенсации нарушенных функций / Д. С. Саркисов. - М. : Медицина, 1998. - 230 с

7. Сорочинников А. Г. Гистологическая и микроскопическая техника / А. Г. Сорочинников, А. Е. Доросевич. - М. : Медицина, 2007. - 448 с.

8. Шорманов С. В. Гистологические и ультраструктурные изменения печени при экспериментальном стенозе легочного ствола на стадии декомпенсации / С. В. Шорманов, С. В. Куликов // Морфология. - 2010. - № 3. - С. 46-50.

yakh Excell [Statistical methods in medicobiological investigations Excell]. Kyiv: Morion [in Ukrainian].

5. Lukianova, O.M. (2002). Aktualni problemy perynatolohii na suchasnomu etapi okhorony zdorovia [Actual problems of perinatology on the present stage protection of health]. Perynatolohiia ta pediatriia - Perynatology and Pediatrics, 3, 3-6 [in Ukrainian].

6. Sarkisov, D.S. (1998). Strukturnye osnovy adaptatsii kompensatsii narushennykh funktsiy [Structural basis adaptation and compensation damage function]. Moscow: Meditsyna [in Russian].

7. Sorochinikov, A.G., \& Dorosevich, A.Ye. (2007). Gestologicheskaya i mikroskopicheskaya tekhnika [Histological and microscopic equipments]. Moscow: Meditsyna [in Russian].

8. Shormanov, S.V., \& Kulikov, S.V. (2010). Gistologichieskie i ultrastrukturnye izmineniya pechieni pri eksperimentalnom stenoze legochnogo stvola na stadii dekompensatsyi [Histological and ultrastructural changers of liver at experimental stenosis of pulmonary trunk at insuficience]. Mofrologiya - Morphology, 3, 46-50 [in Russian] 